\title{
PREGLED FOTOGRAFA I FOTOGRAFSKIH ATELJEA NA TERITORIJI BOSNE I HERCEGOVINE KROZ FOTOGRAFSKU GRAĐU ZAOSTAVŠTINE MARICE VOJNOVIĆ U ZAVIČAJNOM MUZEJU U VISOKOM
}

\author{
Habiba Efendira-Čehić \\ JU “Zavičajni muzej” Visoko \\ habi.cehic@gmail.com \\ Dženana Arnautović \\ Visoko, Bosna i Hercegovina \\ dzenanaarnautovic@yahoo.com
}

\begin{abstract}
Apstrakt: Fotografska građa iz zaostavštine Visočanke Marice Vojnović (1892-1982) dio je fundusa Zavičajnog muzeja u Visokom od 1981. godine. Građa je datirana u period od kraja 19. do sedamdesetih godina 20. stoljeća i doprinosi izučavanju razvoja fotografije, ističe značaj fotografije kao medija i ukazuje na pojavu fotografskih ateljea u Bosni i Hercegovini. Na osnovu podjele fotografske građe iz zaostavštine Marice Vojnović u radu se daje uvid u imena 23 fotografa i fotografska ateljea koji su djelovali na teritoriji Bosne i Hercegovine: Sarajevo, Višegrad, Visoko, Nevesinje i Zavidovići, a čije su fotografije zastupljene u zaostavštini. Među njima su poznata imena prvih sarajevskih ateljea, ali i ona manje poznata dosadašnjoj javnosti, poput imena fotografa: Grimberg, Seraphine Sperling, Cabinet Portrait i Visit Portrait, koji u Bosnu i Hercegovinu dolaze kao putujući fotografi nakon 1876. godine. U radu se skreće pažnja na prve akademske fotografe na domaćem tlu, njihovo učešće na inostranim izložbama kao pionire u dokumentarnoj, reportažnoj, umjetničkoj i filmskoj fotografiji. Fotografska građa iz zaostavštine Marice Vojnović neodvojivi je dio historije bosanskohercegovačke fotografske baštine i njen je značaj višestruk.
\end{abstract}


Ključne riječi: zaostavština, Marica Vojnović, Zavičajni muzej Visoko, fotografija, fotografi, fotografski atelje

\begin{abstract}
The photographic material from the legacy of Marica Vojnović from Visoko (1892-1982) has been part of the holdings of the Regional Museum in Visoko since 1981. The material is dated to the period from the end of the $19^{\text {th }}$ century to the seventies of the $20^{\text {th }}$ century. It contributes to the study of the development of photography, emphasizes the importance of photography as a medium and points to the emergence of photographic studios in Bosnia and Herzegovina. Based on the division of photographic material from the legacy of Marica Vojnović, the paper provides an insight into the names of 23 photographers and photographic studios that operated in Bosnia and Herzegovina: Sarajevo, Višegrad, Visoko, Nevesinje and Zavidovići, and whose photographs are represented in the legacy. Among them are the names of the first Sarajevo studios, but also those less known to the public, such as the names of photographers Grimberg, Seraphine Sperling, Cabinet Portrait and Visit Portrait who came to Bosnia and Herzegovina as traveling photographers after 1876. The paper draws attention to the first academic photographers on domestic soil, their participation in foreign exhibitions as pioneers in documentary, reportage, art and film photography. The photographic material from the legacy of Marica Vojnović is an inseparable part of the history of Bosnia and Herzegovina's photographic heritage and its significance is manifold.
\end{abstract}

Key words: Legacy, Marica Vojnović, Regional Museum of Visoko, Photography, Photographer, Photographic studio

\title{
Zaostavština Marice Vojnović
}

Marica Vojnović (1892-1982), aktivna članica istaknutog Srpskog pjevačkog društva "Milutinović" i dramske sekcije "Milutinović" ostavila je veliki pečat u kulturnim, umjetničkim i historijskim dešavanjima u Visokom tokom prve polovice 20. stoljeća. ${ }^{1}$ Jedan od važnijih historijskih događaja koji su obilježili početak 20. stoljeća u Bosni i Hercegovini bila je posjeta Franje Josipa I, cara i kralja Austro-Ugarskog Carstva, 30. maja 1910.

\footnotetext{
${ }^{1}$ Idriz Džajić, Djelovanje nacionalnih kulturno-prosvjetnih društava u Visokom 1903-1949, Visoko: Ban publishing, 2014, 353-371.
} 
godine. ${ }^{2}$ Tom prilikom car je posjetio i Visoko te je pri svečanom programu prijema Pjevačko društvo "Milutinović" otpjevalo Carevku, službenu himnu Carstva. Upravo je Marica Vojnović bila jedna od pet djevojaka koje su vokalnom izvedbom himne dočekale cara. ${ }^{3}$ Sve do pred Drugi svjetski rat Marica Vojnović je učestvovala u brojnim aktivnostima društva "Milutinović", nakon čega se povlači s javne scene. Teška bolest, duboka starost i samački život bili su razlog zbog kojeg je na zahtjev nadležnih općinskih institucija i Centra za socijalni rad u Visokom 1981. zbrinuta u Dom za stara i iznemogla lica u Nedžarićima u Sarajevu.

Zavičajni muzej Visoko od 1981. godine, tačnije od januara 1981. godine, preuzima na čuvanje dio ove bogate i značajne zaostavštine koja pripada periodu od kraja 19. do sedamdesetih godina 20. stoljeća. ${ }^{4}$ Dio muzejskoga fundusa postala je tako pokretna imovina, tačnije pokućstvo, predmeti sakralne i profane umjetnosti, lični dokument i obiman fotografski materijal, koji su raspoređeni u dvije muzejske zbirke - etnografsku i umjetničku, dok je fotografska građa postala dio muzejske fototeke. Značaj zaostavštine je ogroman. Pruža bogate etnološke izvore o pravoslavnim visočkim porodicama, neiscrpne izvore istraživanja na polju primijenjenih i likovnih umjetnosti za navedeni period, a fotografski materijal, koji najvećim dijelom čine fotoalbumi višedecenijskih rodbinskih i prijateljskih veza porodice Vojnović, izvor su informacija za različita etnološka i historijska istraživanja na teritoriju Bosne i Hercegovine, ali i šire.

\section{Fotografska građa iz zaostavštine}

Fotografski materijal s preko 170 fotografskih jedinica najobimniji je dio zaostavštine. Nastajao je od kraja 19. do sedamdesetih godina 20. stoljeća, u periodu u kojem su nastupili značajni historijski događaji koji su uveliko promijenili svijet: Prvi i Drugi svjetski rat, brojna i značajna naučna otkrića,

\footnotetext{
${ }^{2}$ Franjo Josip, “Historička 1910., Bošnjak: kalendar za prostu godinu 1911, 1911, 45-1.

${ }^{3}$ Isto, 52. (Po fotografiji Fr. Topića. Naziv fotografije: Doček u Visokom. Djevojke pjevaju Carevku.)

${ }^{4}$ Ulazna knjiga muzejskog materijala br. 289, 5. 1. 1981; Inventarna knjiga Etnografske zbirke, 260.
} 
industrijalizacija itd. Razvoj i reproduciranje fotografije, općenito, utjecali su na populistički trend sakupljanja i stvaranja fotografskih albuma porodičnih fotografija, vizitkarti, dopisnih karti, novinskih isječaka. Fotografska građa Marice Vojnović nastala je kao porodični album u kojem su fotografije i dopisne karte veza s članovima rodbine i prijatelja nastanjenih na tlu današnje Bosne i Hercegovine, Hrvatske, Srbije, Austrije, Mađarske i Češke.

Spomenutu građu čine lični dokument, novinski članci, dopisne karte i fotografije. Lični dokument s fotografijom Marice Vojnović vrsta je putničke knjižice s vlastoručnim potpisom vlasnice. Dio materijala čini i jedan primjerak isječka iz novinskog članka na kojem je izrezana fotografija ženskog portreta. Dopisne karte različitih su motiva. Sistematizacijom je izvršena podjela na dopisne karte s prazničnim motivima - čestitke, seoske pejzaže, gradove, reprodukcije umjetničkih djela, poznate ličnosti i dopisne karte s fotografijama. Među dopisnim kartama tri su primjerka s ručno obojenim, štampanim motivima. Od fotografija u kolor tehnici našla se samo jedna novije datacije. Prema karakteru fotografskog snimka, fotografije su podijeljene na portretne i dokumentarne. Većina fotografija s dokumentarnim predznakom odnosi se na porodična i prijateljska okupljanja, dešavanja i slave, ali su zastupljene i fotografije sa zabilježenih javnih skupova, koji su se održavali povodom nekih historijskih događaja.

Fotografsku građu u osnovi čine pozitivi smeđih i crno-bijelih tonova, koji u nijansama variraju u zavisnosti od tehnike izrade i stanja očuvanosti. Mnoge od njih izrađene su na pripremljenom ili gotovom fotografskom papiru, dok su najstarije kaširane na kartonsku podlogu. Nažalost, neke od njih oštećene su postupkom skidanja s kartonske podloge. Kaširane fotografije nastaju početkom druge polovine 19. stoljeća, prvobitno pojavom kartomanije, kada se fotografija lijepi/kašira na karton na kojem su štampani ukrasni tekstualni natpisi s dekorativnom slikovnom vinjetom. ${ }^{5}$

\footnotetext{
${ }^{5}$ Kartomanija je pojava masovne proizvodnje fotografija manjih dimenzija koja je nastala tokom šezdesetih godina 19. stoljeća i već tada postala internacionalna. Veže se za novi tip fotografije veličine vizitkarte, cca $10 \times 6 \mathrm{~cm}$, kaširane za kartonsku podlogu. Novi patent fotografije osmislio je André Adolphe Disdéri 1854. godine snimajući različite motive i portrete kamerom s osam ili više objektiva, kako bi dobio osam ili više negativa na jednoj staklenoj ploči. Proizvod je bio
} 
U konačnom obliku takav proizvod predstavlja fotografiju s podsjetnicom na adresu fotografa ili fotografskog ateljea, tačnije fotografiju s vizitkartom fotografa. Primjerci kaširanih fotografija iz fotografske građe zaostavštine Vojnović datirani su u prijelazni period iz 19. u 20. stoljeće. Standardiziranih dimenzija jesu "cabinet portrait" ili "visit portrait" fotografija, koje i dalje predstavljaju vizitkarte fotografa i fotoateljea. ${ }^{6}$ Fotografije su kaširane na avers posebno dizajnirane kartonske podloge koja je na reversu, poleđini, ukrašena litografijom bečkih umjetnika s popularnim cvijetnim ili antičkim motivima. Neke od litografskih kompozicija, poput vinjete, uokviruju prostor namijenjen za pisanje posvete. Interesantna je činjenica da se $u$ tom periodu skoro svi pozitivi retuširaju, detalji dotjeruju crtežom s ciljem izoštravanja ili uljepšavanja portretisane klijentele. ${ }^{7} \mathrm{Na}$ taj način fotografi skreću pažnju na sebe i grade vlastiti publicitet. Fotografija doživljava procvat početkom 20. stoljeća, a fotografi postaju umjetnici u fotografskim ateljeima i izvan njih. Njihov rad danas predstavlja kulturno-umjetničko naslijeđe i veliki je doprinos istraživanjima razvoja fotografske umjetnosti.

Raznovrsnost fotografske građe iz zaostavštine Marice Vojnović bila je povod za realizaciju online izložbe pod nazivom "Marica Vojnović, Visočanka (1892-1982) - zaostavština predmeta i fotografija s kraja 19. i

jeftiniji, a tim i pristupačniji. Pored ateljea Disdéri je otvorio i fotografsku štampariju u kojoj je svakodnevno nastajalo hiljade fotografskih reprodukcija koje su se dijelile po motivima namijenjenih kolekcionarskim potrošačima iz visokog staleža i prodavale u albumima. Budući da je proizvod bio jeftin, razvio se veliki interes i građanske klijentele koja je sebi mogla priuštiti sakupljanje portreta kraljevskih porodica ili drugih motiva. Opširnije vidjeti: Milanka Todić, Istorija srpske fotografije (1839-1940), Beograd: Prosveta; Muzej primenjenih umetnosti, 1993, 41-42.

${ }^{6}$ Za razliku od fotografija koje su dimenzija vizitkarte cca $10 \times 6 \mathrm{~cm}$, fotografije kabinetskog tipa nešto su većih dimenzija - cca $16 \times 10 \mathrm{~cm}$.

7 Tokom prve polovine 19. stoljeća pripadnice ženskog spola pobunile su se protiv fotografije zbog fotografskih tehnika, koje su bilježile i najsitnije detalje. Na primjer, nedostatak tehnike dagerotipije (1941) bio je taj što je portretisano lice bilo zatamnjeno (crno), što je bilo daleko od recentnog pojma ljepote. Daljim usavršavanjem fotografije nastale su tehnike koje su omogućile kvalitetniji snimak, ali i retuš. Idealu ljepote težilo se u tolikoj mjeri da se do kraja 19. stoljeća retuš javlja na svakoj studijskoj fotografiji, a najbolji fotografi bili su oni s najbogatijim rekvizitima (crtački pribor). Opširnije vidjeti: Branibor Debeljković, Stara srpska fotografija, Beograd: Muzej grada Beograda; Muzej primenjenih umetnosti, 1977, 9, 24. 
početkom 20. stoljeća" koja je poslužila kao temelj za dalja istraživanja.$^{8} \mathrm{Na}$ osnovu podjele fotografske građe bilo je moguće sačiniti pregled fotografa i fotografskih ateljea, ukupno njih 23, koji su djelovali na teritoriji Bosne i Hercegovine od kraja 19. stoljeća do 1955. kada je datirana posljednja fotografija iz zaostavštine.

\section{Pregled fotografa i fotografskih ateljea iz zaostavštine}

Otkriće novog medija, fotografije, zvanično je objavljeno u Parizu na sjednici francuske Akademije nauka održanoj 19. augusta 1839. godine, kada je francuski naučnik François Arago detaljno izložio osobine novog otkrića nazvanog "dagerotipija", kojom se na ravnu površinu ploče prenosila vjerna slika stvarnosti. ${ }^{9}$ Fotografija je u velikoj mjeri utjecala na život čovječanstva. Izmijenila je odnos prema vizuelnom mediju i unutar njega. Bila je dokument vremena u kojem je nastala, tehnologije, namjera i vještine autora, života i vlastitog značenja u određenim sredinama čime je zadovoljavala kriterije učestvovanja u stvarnosti, ali i dokument zbivanja koja je bilježila ili predmetnog svijeta što ga je prenosila iz stvarnosti u odslik ili u drugu dimenziju postojanja. ${ }^{10}$ Prvi fotografski ateljei u Bosni i Hercegovini otvoreni su za

${ }^{8}$ Online izložba Zavičajnog muzeja u Visokom "Marica Vojnović, Visočanka (1892-1982) - zaostavština predmeta i fotografija s kraja 19. i početkom 20. stoljeća" realizirana je povodom obilježavanja Međunarodnog dana i Evropske noći muzeja 2020. Na izložbi je predstavljen dio fotografske građe s osnovnim podacima i fotoreprodukcijama koje se prate kroz slajdove, a na koje se poziva u ovom radu. S tim u vezi potrebno je istaći da se prilikom publikovanja preliminarnih podataka potkralo nekoliko grešaka nastalih u nedostatku raspoloživih informacija pri tadašnjem radu. Daljim istraživanjem i prikupljanjem relevantnih podataka o fotografskoj građi i dataciji pojedinih primjeraka iz zaostavštine Marice Vojnović utvrđeno je da se datacija fotografije Portret mladih dama Marice $i$ Natalije Vojnović (slajd br. 5) ograničava na početak 20, a ne 19. stoljeća, kako je prvobitno napisano za potrebe izložbe. Pored toga, za autora fotografije Portret dječaka s drvenim konjićem (slajd br. 36) pogrešno je navedeno ime sarajevskog fotografa M. Karahasanovića kao Muhamed o čijem je fotografskom angažmanu s novim podacima moguće detaljnije pročitati u nastavku ovog rada. Vidi: https:/www.zavicajnimuzej.com/wp-content/uploads/2020/05/MaricaVojnovicbosanski.pdf.

${ }^{9} \mathrm{M}$. Todić, Istorija srpske fotografije (1839-1940), 17.

${ }^{10}$ Determinacija fotografskog materijala u muzeju dugotrajan je posao jer zahtijeva poznavanje fotografiranih osoba, događaja, materijala i tehnika i bez zapisanih podataka na poleđini ili vjerodostojne legende fotografija je neupotrebljiva za muzejske djelatnike i istraživače. Opširnije 
vrijeme namjesništva Topal Osman-paše (1861-1869), koji je ostao poznat po brojnim reformama u Bosanskom vilajetu. ${ }^{11}$ Počeci fotografije u Bosni i Hercegovini vezuju se za ime novosadskog slikara i putujućeg fotografa Georgija Knesevića, koji 1855. godine dolazi u Sarajevo i snima prve fotografije na svadbi trgovca Gavre i Dare Jelić. ${ }^{12}$ Moguće je pretpostaviti da je prva fotografska radnja u Sarajevu otvorena 1862. godine. U prilog tome govori privatno pismo iz korespondencije trgovačke kuće Hadžiristić iz januara 1863. godine u kojem se spominjala jedna fotografija. Naime, na fotografiji je vjerovatno bio sam Vaso s obzirom na to da mu Mihajlo Tasovac odgovara kako je lijepo ispao i dodaje kako im se fotografija puno dopada. ${ }^{13}$ Godine 1866 . u Bosanskom vjestniku spominje se fotograf Bottini Pesante. Ovaj Italijan je na prijemu kod vezira u augustu 1866. godine snimio i jednu grupnu fotografiju koja nije sačuvana, ali je detaljno opisana u članku pod nazivom Fotografska slika. ${ }^{14}$ Pesante, vlasnik fotoateljea, putem sedmične štampe obavijestio je zainteresirane mušterije da će se u njegovoj fotografskoj radnji: “[...] svaki dan vaditi slike u velikom i malom razmjeru, grupe s više lica i vizitne slike. Za vađenje slika načinjena je jedna topla (staklena) komora u kojoj će se moći u svako vrijeme vaditi spomenute slike. Vrijeme vađenja slika naznačava se od 6 do 11 sahata po turski. Fotografija se nalazi u kući g. Velibeja, đe je prije bio italijanski konzulat."15 Također, Hana Younis piše da "sarajevska trgovačka elita ne samo da se fotografisala nego su pratili i svjetske trendove, te su po uzoru na evropske zemlje počeli sa slikanjem mrtvih osoba. Na to ukazu-

vidjeti: Ivo Maroević, “Fotografija kao muzejski predmet”, Informatica museologica, vol. 31, No. 3-4, Zagreb: Muzejski dokumentacioni centar, 2002, 13-16.

${ }^{11}$ Hana Younis, Svakodnevni život u Sarajevu 1850 -1878, Sarajevo: Centar za osmanističke studije, 2019, 21.

${ }^{12}$ Knesevićeve fotografije rađene su na slanoj hartiji, te su zbog toga žućkaste boje i bez kontrasta. Koristio se talbotipnim negativom, a fotografije nastale kasnijih godina mnogo su kvalitetnije. Nikola Marušić, Istorija fotografije u Bosni i Hercegovini do 1918, Tuzla: Foto-savez Bosne i Hercegovine, 2002, 61.

${ }^{13}$ Hana Younis, Od dućana do pozorišta: Sarajevska trgovačka elita 1851-1878, Sarajevo: Institut za historiju, 2017, 24.

${ }^{14}$ Bosanski vjestnik, Sarajevo: Sopronova pečatnja, 1866, br. 18, god. I, 144.

${ }^{15}$ H. Younis, Svakodnevni život u Sarajevu 1850-1878, 22. 
je jedna veoma interesantna fotografija porodice Alekse Despića koja stoji pored otvorenog kovčega, a najvjerovatnije je fotografija njegove majke."16 Nakon 1878. godine, postavši dijelom Austro-Ugarskog Carstva, u Bosnu i Hercegovinu dolaze putujući fotografi kao i zvanični putujući fotografi vojske sa zadatkom da dokumentiraju rad nove vlasti, ali i da snime bosanske neobičnosti. Ovo je period u kojemu se fotografija institucionalizira i otvaraju se prvi stalni fotografski ateljei. Prvi stalni fotoatelje otvara bečki fotograf Anton Schädler na Appelovoj obali. ${ }^{17}$ Prvo fotografsko udruženje, uopće u Bosni i Hercegovini, osnovano je 1910. pod nazivom Udruženje profesionalnih fotografa Bosne i Hercegovine, dok je 1925. godine osnovano Društvo amater fotografa Sarajevo, čije se djelovanje prvobitno odnosilo na sarajevsku oblast, da bi se kasnije proširilo na Bosnu, Hercegovinu i Dalmaciju. ${ }^{18}$

Analizom fotografskog materijala nastalog u bosanskohercegovačkim fotografskim ateljeima, koji čine sastavni dio zaostavštine Marice Vojnović, zabilježen je rad 23 fotografa, koji su od 1878. godine otvarali fotografske ateljee i činili novi medij bliskim i dostupnim domaćem stanovništvu. Za očekivanje je da je najviše fotografskih ateljea bilo otvoreno u Sarajevu, bosanskohercegovačkoj prijestolnici, koja je u većini slučajeva bila prvi izbor stranim umjetnicima i zanatlijama. Pored Sarajeva zabilježeno je nekoliko fotografskih ateljea u Višegradu, Visokom, Nevesinju i Zavidovićima. Mnogo je stranih fotografa koji su mahom dolazili iz skoro svih zemalja Austro-Ugarskog Carstva, Njemačke i Italije, ali prisutan je i značajan broj domaćih fotografa, koji su nakon završenog studija fotografije ili fotografskog zanata odlučili otvoriti fotografske atelje i na taj način dati doprinos historiji fotografije u Bosni i Hercegovini.

$\mathrm{Na}$ osnovu građe zastupljene u zaostavštini Marice Vojnović među prvim fotografima koji dolaze u Bosnu i Hercegovinu bili su Grimberg i

\footnotetext{
${ }^{16} \mathrm{H}$. Younis, Od dućana do pozorišta, sarajevska trgovačka elita, 246.

${ }^{17}$ Alma Leka, "Udruženje profesionalnih fotografa Bosne i Hercegovine i Društvo amater fotografa Sarajeva: Iz rada prvih bosanskohercegovačkih fotografskih društava”, u: Historijska traganja, br. 8, Sarajevo: Institut za istoriju, 2011, 83.

${ }^{18}$ Isto, 84-92.
} 
Seraphine Sperling, čiji su se fotografski ateljei nalazili u Višegradu. Riječ je o kaširanim fotografijama koje su nastale na prijelazu iz 19. u 20. stoljeće. Grimbergov Portret dječaka na klupi ${ }^{19}$ nastaje "na otvorenom", što govori o činjenici da fotografi u tom periodu već uveliko izlaze iz studija, idu na teren sa svojom opremom i fotografišu na otvorenom dnevnom svjetlu koristeći se svojim znanjem i umijećem.

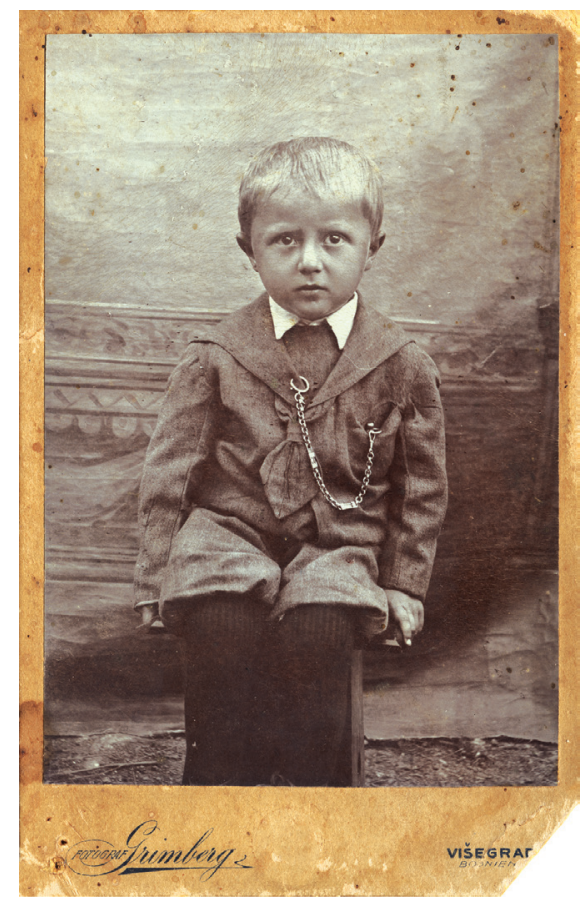

Fotograf Grimberg. Višegrad. Portret dječaka na klupi.

10,4 x 16,3 cm. Ne prije 1905. - ne poslije 1912.

(KV FZMV, inv. br. 1996/103)

Sperling je imao fotoatelje u Bosni i Hercegovini, ali je povremeno odlazio i na teritorij današnjeg Sandžaka u potrazi za poslom. Kratko je boravio u Priboju i okolini kao putujući fotograf. Fotografije u Priboju nastale su

\footnotetext{
${ }^{19}$ Fototeka Zavičajnog muzeja Visoko (dalje: F ZMV), Kolekcija fotografija iz zaostavštine Marice Vojnović (dalje: KV FZMV), inv. br. 1996/103. Fotograf Grimberg. Višegrad. Portret dječaka na klupi. Ne prije 1905. - ne poslije 1912.
} 
van ateljea, najvjerovatnije $\mathrm{u}$ dvorištu fotografisanih osoba. Na njegovim fotografijama uočava se korištenje tehnike ferlauf, tj. tehnike sjenčenja, što je fotografijama davalo novu dimenziju, a portretisanim licima dozu ljepote. ${ }^{20}$ Jedna od takvih fotografija je i Portret bračnog para M. A. Curovićeve $i$ S. Stojkovića na kojoj su primjetni sitni retuši kojima Sperling vješto naglašava detalje portreta ili odjeće. ${ }^{21}$

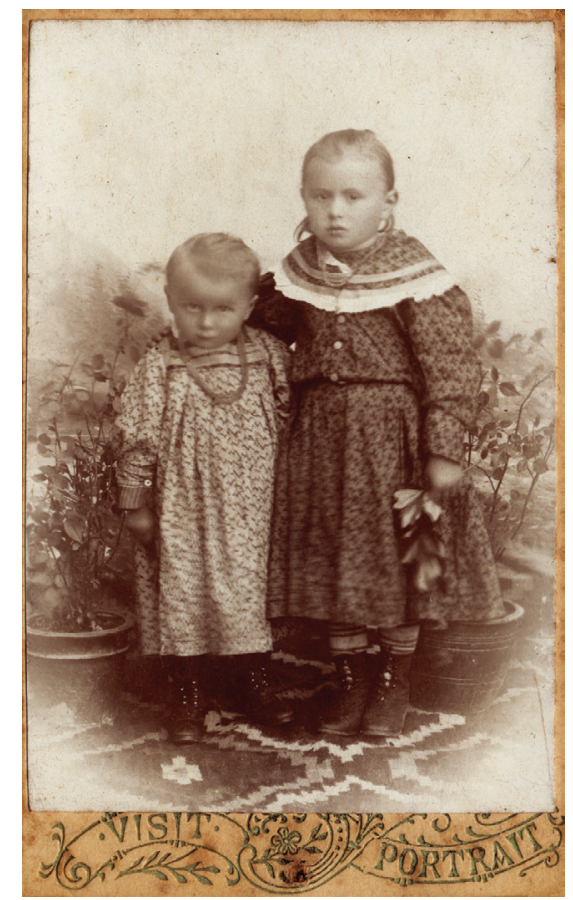

Visit Portrait. Višegrad (?). Portret dvije djevojčice.

$6,5 \times 10,4 \mathrm{~cm}$. Ne prije 1890 . - ne poslije 1910.

(KV FZMV, 1996/106)

\footnotetext{
${ }^{20}$ FotoMuzej - Virtuelni muzej srpske i svetske fotografije. Vidi: http://www.fotomuzej.com/ateljeserafin-sperling.266.html (pristupljeno: 8. 6.2020)

${ }^{21}$ KV FZMV, inv. br. 1996/99. Photographiches Atelier Seraphine Sperling. Višegrad. Bračni par Milenija A. Ćurovićeva i Svetozar (Ž?) Stojković Dobrun - Bosna, Sereni, Kragujevac. Ne prije 1895. - ne poslije 1910. Vidi: slajd 8-9, https://www.zavicajnimuzej.com/wp-content/uploads/2020/05/ MaricaVojnovicbosanski.pdf.
} 
Za fotografije Visit Portrait i Cabinet Portrait pretpostavlja se da su snimci stranih putujućih fotografa koji su boravili u Bosni i Hercegovini krajem 19. i početkom 20. stoljeća. ${ }^{22}$ Ono što je neuobičajeno za ove fotografije jeste da nemaju napisane adrese ateljea na poleđini, a što je bilo karakteristično za ovaj period..$^{23}$

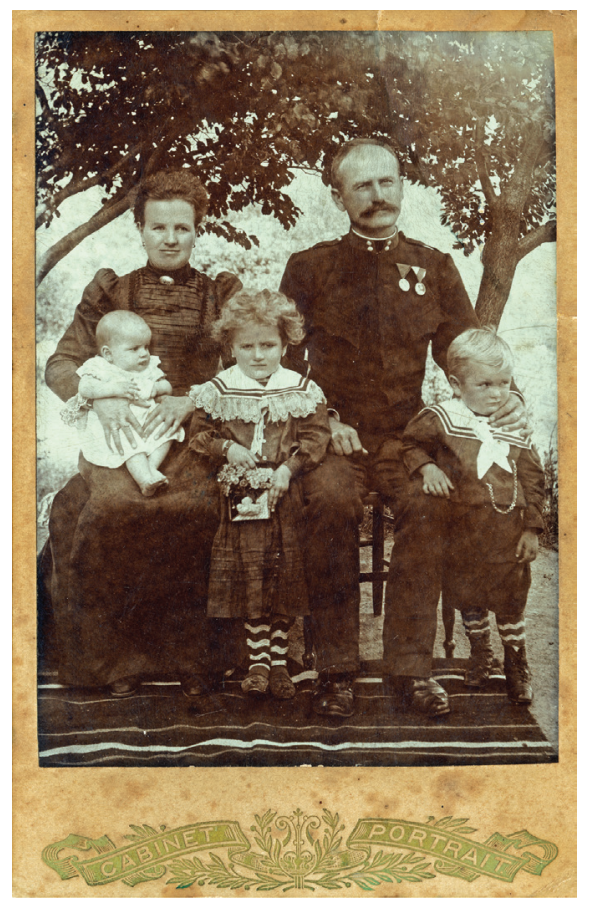

Cabinet Portrait. Višegrad (?).

Porodični portret. 10,5 x 16,3 cm. Ne prije 1895. - ne poslije 1907.

(KV FZMV, inv. br. 1996/101)

${ }^{22}$ KV FZMV, inv. br. 1996/106. Visit Portrait. Višegrad (?). Portret dvije djevojčice. Druga polovina 19. stoljeća. KV FZMV, inv. br. 1996/101. Cabinet Portrait. Višegrad (?). Porodični portret. Druga polovina 19. stoljeća.

${ }^{23}$ Iako su ovo dva različita naziva, u osnovi se radi o istom proizvodu, preteči vizitkarte. Ono što je karakteristično za većinu fotografija ove vrste jeste da je na prednjoj strani kaširane podloge bio utisnut naziv "cabinet portrait" ili "visit portrait" ne otkrivajući naziv fotografa ili fotoateljea kao ni adresu. Opširnije vidjeti: The Museum of Family History. http://www.museumoffamilyhistory. com/pse-4.htm\#ALBUMEN\%20PRINT (pristupljeno: 24. 7. 2020) 
Kako ih nije bilo moguće posmatrati kao vizitkarte fotografa, pristupilo se metodi komparacije s ostalim fotografijama iz zaostavštine. Glavna referenca bila je fotografija na kojoj je prikazana vojnička zabava na Bikavcu u Višegradu na kojoj se vrlo vjerovatno nalaze i osobe s ove dvije fotografije. ${ }^{24}$

Jedan od prvih sarajevskih fotoateljea otvorio je Samuel S. Abinun. U Sarajevskom listu ostalo je zabilježeno da je "Upisana u trgovački registar za inokosne tvrtke trgovačka tvrtka Samuel S. Abinun, fotografski zavod u Sarajevu. Vlasnik te tvrtke jeste Samuel S. Abinun iz Sarajeva, te će istu vlastoručno latinicom potpisivati. Okružni sud. Sarajevo, 7. juna 1905. br. 3780/civ." ${ }^{25}$ U općem adresnom priručniku Bosanskom glasniku (Bosnicher Bote) zabilježeno je da je fotoatelje Abinun radio tokom 1908. 1909. 1910. i 1913. godine. ${ }^{26}$ Fotoatelje se nalazio u Ulici Franje Josipa na broju 68. I, u Bosanskom glasniku navodi se da je fotografski atelje Samuela Abinuna otvoren 1905. godine. Međutim, Abinun je radio i fotografisao u Sarajevu i prije otvaranja ateljea. Tako su zabilježene njegove dvije fotografije datirane ne poslije 1895. Riječ je o kaširanim fotografijama. Na prednjoj strani navedeno je ime i prezime fotografa te naziv grada Sarajevo. ${ }^{27}$ Abinun je bio vrsni portretista. Posebnu pažnju posvećivao je fotografisanju ženskih osoba u tradicionalnoj nošnji naglašavajući elemente koji su bili sastavni dio osmanske tradicije. Tako je pokazivao svoj interes za kulturu stanovništva s kojim je živio, ali nije zanemarivao ni studijske portrete dama u modernoj gradskoj nošnji popraćenih detaljem koji naglašava njihovu mladost i ljepotu, poput cvijeća u ruci mlade dame. ${ }^{28}$ Pretpostavlja se da je preminuo

\footnotetext{
${ }^{24}$ KV FZMV, inv. br. 1996/25. Nepoznat fotograf. Vojnička zabava na Bikavcu u Višegradu. Ne prije 1900. - ne poslije 1912.

${ }^{25}$ Sarajevski list, Sarajevo: Štampa zemaljske štamparije, 1905, br. 83, god. XXVIII.

${ }^{26}$ Bosanski glasnik opći adresni priručnik sa kalendarom svih vjeroispovijesti za Bosnu i Hercegovinu, Sarajevo; Beč, 1908, 350. Isto (1909), 201. Isto (1910), 209. Isto (1913), 307.

${ }^{27}$ Studijski portret gradske žene i Žena muslimanka odjevena u tradicionalnu nošnju za izlazak iz kuće. Fotografije se nalaze u arhivu Muzeja Sarajeva. Vidi: Visual Archive Southeastearn Europe. https://gams.uni-graz.at/context:vif (pristupljeno: 15. 7. 2020)

${ }^{28}$ KV FZMV, inv. br. 1996/104. Samuel S. Abinun. Sarajevo. Portret dame. Ne prije 1895. - ne poslije 1910.
} 
tokom 1915. godine i da je ukopan na sarajevskom jevrejskom groblju. ${ }^{29}$

Među fotografima koji su u velikom broju počeli stizati u Bosnu i Hercegovinu oko 1895. godine bio je i fotograf Emanuel/Emil Buchwald ${ }^{30}$ čiji se fotoatelje nalazio u Ćemaluša ulici br. $161 .{ }^{31}$ Prvi podaci o Buchwaldovom fotoateljeu jesu iz 1905. godine kada je zabilježen kao jedan od sarajevskih fotografa. ${ }^{32}$ Sarajevski list spominje da je fotoatelje bio zatvoren tokom 1915. godine, pri čemu navodi da se "u ovosudnom trgovačkom registru za inokosne tvrtke briše tvrtka Emanuel Buschwald sa nastankom u Sarajevu, fotografički atelier, jer je istoimeni vlasnik posao napustio. Okružni sud Sarajevo, 27. marta 1915." ${ }^{33}$ Atelje je ponovo otvoren već tokom naredne godine. Istovremeno fotograf Buchwald spominje se i kao član Sarajevskog šahovskog kluba i učesnik nekoliko šahovskih turnira koji su organizovani u Sarajevu. ${ }^{34} \mathrm{Na}$ osnovu oglasa u Sarajevskom listu znamo da je Bernhard Buchwald posjedovao knjižaru u Sarajevu koja je otvorena 1890. godine. ${ }^{35}$ Moguće je pretpostaviti da su Emanuel i Bernhard bili u rodbinskoj vezi te da su zajedno radili. Emanuel je fotografisao, dok je Bernhard umnožavao fotografije štamparskim postupkom. U Emanuelovom fotografskom radu zastupljeni su svi žanrovi: portreti, urbani motivi, arhitektura i dokumentarni snimci koje je Bernhard štampao u formi fotografskih albuma (leporello - "harmonika" album). Jedan od primjeraka ove vrste albuma našao

${ }^{29}$ Vidi: Visual Archive Southeastern Europe. https:/gams.uni-graz.at/context:vase. (pristupljeno: 15. 7. 2020)

${ }^{30}$ Bosanski glasnik, 1907, 196. Isto: (1908), 350; (1909), 201; (1910), 209; (1912), 302; (1913), 307; (1916), 180; (1917), 164; (1918), 372.

${ }^{31}$ Navedena adresa sastavni je dio fotografije pored imena i prezimena fotografa. Nikola Marušić navodi još jednu adresu ovog fotoateljea: Ulica Ćemaluša br. 183. N. Marušić, Istorija fotografije u Bosni i Hercegovini do 1918, 61.

${ }^{32}$ Bosanski glasnik, 1905, 174.

${ }^{33}$ Sarajevski list, 1915, br. 103, god. XXVIII, 5.

${ }^{34}$ Sarajevski list, 1914, br. 66, god. XXVII, 3.

35 "Kod okružnog suda u Sarajevu pod današnjim danom i gornjim brojem upisana je u trgovački registar za inokosne tvrtke, tvrtka "B. Buschwald” knjižara, sa nastanom u Sarajevu, koju će potpisivati vlasnik Bernhard Buchwald iz Sarajeva.” Okružni sud, Sarajevo, 10. maja 1890. Vidi: Sarajevski list, 1890, br. 65, god. XIII. 
se na online stranici hrvatske aukcijske kuće Barac \& Pervan pod nazivom "Uspomena na 10.- 12. oktobar 1909. - SARAJEVO - Bos. Her. Trgovačko društvo. Emanuela Buchwalda”." ${ }^{36}$ Sastoji se od 16 fotografija Sarajeva dimenzija 16 x $11 \mathrm{~cm}$ iz 1909. u originalnom uvezu. Buchwaldova fotografija iz fotografske građe zaostavštine Marice Vojnović pripada grupi kaširanih fotografija na kojoj je snimljen studijski portret mladića u anfasu. ${ }^{37}$

Jedan od saradnika na izradi godišnjaka Bošnjak ${ }^{38}$ bio je fotograf Färber Heinrich, koji u Sarajevo dolazi oko 1900. godine. Njegov fotografski atelje nalazio se na adresi Appelquai broj 54, a nešto kasnije u Ulici Franje Josipa br. $15 .{ }^{39}$ U Sarajevskom listu iz 1913. i 1914. godine zabilježeni su oglasi u kojima se Atelier Färber reklamira povodom božićne i uskršnje sezone, a tokom 1916. i 1917. godine potražuje jednog izučenog fotografa. ${ }^{40}$ Heinrichov rad je specifičan po svojoj originalnosti i živosti portretisanih osoba, pri čemu je bio dosljedan studijskoj fotografiji. Koristio je neutralne pozadine naglašavajući figuru, što je uveliko uticalo na izvrsnost portreta, ističući je uz pozadinske elemente poput kaneliranog stupa ili baroknog naslonjača, koji su davali portretisanoj klijenteli dozu aristokratije. ${ }^{41}$

Walter Tausch, fotograf i fotoreporter izuzetnih kvaliteta, bio je vlasnik fotoateljea u Sarajevu i jedan od omiljenih fotografa Sarajlija. U fotografskoj građi iz zaostavštine nalazi se osam fotografija iz Tauschevog fotoateljea koje su nastajale tokom dugogodišnjeg bavljenja fotografisanjem. Od

${ }^{36}$ Aukcija Barper.com: aukcija br. 47 - Knjige, zemljovidi, plakati. Kataloški broj: 1004. Kategorija: Bosna i Hercegovina. http://www.barper.com/hr/aukcija/predmet/sarajevo-savrseno-ocuvan-leporello-(album---harmonika)-sa-16-fotografija-sarajeva-1909,1562.html\#ad-image-0 (pristupljeno: 15. 7. 2020)

${ }^{37}$ KV FZMV, inv. br. 1996/98. EM. Buchwald. Sarajevo. Portret Danila Vojnovića, 28. 1. 1907.

${ }^{38}$ N. Marušić, Istorija fotografije u Bosni i Hercegovini do 1918, 166.

${ }^{39}$ Appelquai i Ulica Franje Josipa jesu ulice koje su dobile nazive tokom austrougarske uprave i zadržale ih sve do 1918. godine. Danas su to ulice Obala Kulina bana i Branilaca Sarajeva.

Vidi: http://www.centar.ba/stranica/515; http://www.centar.ba/stranica/505 (pristupljeno: 26. 8. 2020)

${ }^{40}$ Sarajevski list, 1913, br. 251, god. XXXVI, 3. Isto: (1914) br. 60, god. XXXVII, 5; (1916) br. 351, god. XXXIX, 3; (1917), br. 2, god. XL, 3.

${ }^{41}$ KV FZMV, inv. br. 1996/86. Atelier Färber. Sarajevo. Studijski portret Danila i Natalije Vojnović. Ne prije 1900. - ne poslije 1915. 
osam fotografija tri su autorske, dok je pet fotografija nastalo snimkom porodične kamere (Ivica Grabovac) koje su izrađene u fotoateljeu. ${ }^{42}$ Najstarija je fotografija iz 1926. godine signirana pečatom: Slikar Tausch, Sarajevo (dvojezično), zatim iz 1935. a najmlađa iz 1938. godine. Na osnovu popisa sarajevskih svjetlopisača - fotografa u općem adresnom priručniku - zabilježeno je da je Tausch 1908. godine imao registrovan studio za fotografisanje, ${ }^{43}$ dok se 1942. i 1943. godine oglašavao i reklamirao svoj fotoatelje na stranicama kalendara Narodna Uzdanica. ${ }^{44}$ Pored rada u ateljeu bio je angažovan na fotografisanju događaja koji su bili izuzetno važni za prikaz nove austrougarske vlasti. Kamera koju je donio sa sobom zabilježila je brojne historijske trenutke među kojima su posljednje fotografije Franza Ferdinanda i njegove supruge prije atentata i suđenje Gavrilu Principu. Fotografišući događaje koji su obilježili austrougarsku Bosnu i Hercegovinu, Tausch je direktno utjecao na razvoj dokumentarne fotografije u Bosni i Hercegovini koja će sve više privlačiti pažnju fotografa. Autor je reportaže s Baščaršije iz 1918. godine. Naime, snimio je jedan pazarni dan i objavio fotografije u posebnoj mapi. To je svakako jedna od najuspješnijih serija fotografija o sarajevskoj čaršiji svih vremena. ${ }^{45}$ Naročito je uživao u fotografisanju Sarajeva i njegovih znamenitosti, sokaka, mahala i čaršije, lokalnog stanovništva i njihovog tradicionalnog načina odijevanja.

U periodu od 1905. do 1910. u Sarajevu, u Ulici Franza Josefa 21, fotoatelje otvara Elektro-Fotograf. Sudeći prema velikom broju zastupljenih fotografija u fotografskoj građi zaostavštine Marice Vojnović koje su izašle iz ovog ateljea, Elektro-Fotograf bio je studio za izradu minijaturnih portreta. ${ }^{46}$ Većina ih je izrađena u dimenzijama od cca $4 \times 6 \mathrm{~cm}$. Pretpostavlja se

\footnotetext{
${ }^{42}$ KV FZMV, inv. br. 1996/45; 1996/65; 1996/149; 1996/170; 1996/172; 1996/173; 1996/174; 1996/178. Walter Tausch. Sarajevo. 1926-1938. Vidi: slajd 10-11, https://www.zavicajnimuzej.com/wp-content/uploads/2020/05/MaricaVojnovicbosanski.pdf.

${ }^{43}$ Bosanski glasnik, 1908, 350.

${ }^{44}$ Narodna Uzdanica, Sarajevo: 1942, god. X. 1943, god. XI.

${ }^{45}$ N. Marušić, Istorija fotografije u Bosni i Hercegovini do 1918, 98.

${ }^{46}$ KV FZMV, inv. br. 1996/89-94. Elektro-Fotograf. Sarajevo. Ne prije 1905. - ne poslije 1918. Vidi: slajd 33, https://www.zavicajnimuzej.com/wp-content/uploads/2020/05/MaricaVojnovicbosanski.pdf.
} 
da su ove minijaturne dimenzije fotografija bile pogodne za lični prijenos i umetanje fotografije u određene predmete poput privjesaka ili dokumenata, kao što je to i fotografija iz ličnog dokumenta Marice Vojnović nastala u navedenom fotoateljeu. Također, kao i drugi fotografi, Elektro-Fotograf nametnuo se klijenteli svojom vizitkartom iskoristivši i tako malu površinu da na licu štampa ime i adresu ateljea te da je na naličju obilježi pečatom ateljea. Ipak, fotografije nastale iz ovog studija odlikuju se jasnoćom, prozračnim ambijentom i neutralnom svijetlom pozadinom.

Godine 1896. oglašava se u Bosanskoj vili, u dijelu za brzojavne i pismene čestitke, navodeći puno ime i prezime, zanimanje i mjesto boravka: Veljko Đurov Simović, fotograf. Bileće (Hercegovina). ${ }^{47}$ Simović najprije radi kao fotograf u Bileći, da bi 1908. godine otvorio fotoatelje u Nevesinju. ${ }^{48}$ Njegov rad može se pratiti tokom 1908. 1909. 1910. 1913. i 1914. godine. ${ }^{49}$ Jedna od Simovićevih fotografija iz spomenute zaostavštine jeste grupni portret na kojoj devetnaest osoba, odraslih i djece, poziraju fotografu na otvorenom. ${ }^{50}$ Fotografija je vjerovatno nastala u periodu od 1908. do 1914. uzevši u obzir to da se na fotografiji nalazi i prijateljica Marice Vojnović, također članica Srpskog pjevačkog društva "Milutinović" - Višnja Lazarević. ${ }^{51}$ To je moguće pretpostaviti i na osnovu "Gibson frizure" koja je bila popularna u prvoj deceniji 20. stoljeća, a koju dame na fotografiji nose. Simovićevo ime spomenuto je u raspravi zbog veleizdaje u Banjoj Luci: "s toga se spominju stanovnici iz Hercegovine samo iznimice u lozničkim spisima. U glavnom spisku spomenut je samo jedan povjerenik i to: Veljko Simović, fotograf iz Nevesinja, koji je u vezi sa učiteljem Kostom Gnjatićem" ${ }^{52}$ Nakon vijesti o sarajevskom atentatu 1914. godine organizovane su masovne demonstracije i napadi ne samo na Srbe koji su bili politički aktivni već i na srpske trgovačke radnje koje su pljačkane. Uvedene

${ }^{47}$ Bosanska vila, Sarajevo: Srpsko prosvjetno-kulturno društvo Prosvjeta, 1896, br. 13, god. XI, 213.

${ }^{48}$ N. Marušić, Istorija fotografije u Bosni i Hercegovini do 1918, 95.

${ }^{49}$ Bosanski glasnik, 1908, 283. Isto: (1909), 288; (1910), 297; (1913), 431; (1914), 444.

${ }^{50}$ KV FZMV, inv. br. 1996/15. Veljko Đ. Simović. Nevesinje. Fotografija društva u Nevesinju. Ne prije 1908. - ne poslije 1914.

${ }^{51}$ I. Džajić, Djelovanje nacionalnih kulturno-prosvjetnih društava u Visokom 1903-1949, 360.

${ }^{52}$ Sarajevski list, 1916, br. 28, god. XXXIX, 2. 
su brojne restrikcije i ograničenja za srpsko stanovništvo. Pored toga, već na početku rata uvedena pravila vojnog zakonodavstva protumačena su na način da ne postoje smetnje da se u Bosni i Hercegovini i na okupiranim područjima, naredbom nadležnog komandanta, uvede prijeki sud kao zastrašujuća mjera čije će presude potvrđivati vojni zapovjednik. Serija suđenja mogla je da počne. Krenula je od Banje Luke, a završila se u Sarajevu. Državni tužilac je 3. novembra 1915. godine pred sudom u Banjoj Luci optužio za veleizdaju 156 lica. Suđenje je završeno u Banjoj Luci 16. marta 1916. a presuda je izrečena na Veliku subotu, 22. aprila iste godine. Nijedno suđenje do tada nije dobilo publicitet u međunarodnoj javnosti kao ovo, ne samo zbog broja optuženih već i zbog optužbe koja je imala političko obrazloženje. ${ }^{53}$

Fotografski atelier M. Karahasanović djelovao je u Sarajevu u periodu između dva svjetska rata na dvije adrese: Zrinjskog ul. 4 (ili 11) i Aleksandrova $1 .{ }^{54}$ Najvjerovatnije da se radilo o porodičnoj fotografskoj radnji, koja je tokom druge polovine XX stoljeća ostala zapamćena na adresi Hotela Gazi, u krugu zanatsko-trgovačkih prostorija Gazi Husrev-begovog vakufa. ${ }^{55}$ Prvi pisani podatak o djelovanju fotografskog ateljea Karahasanović datira iz 1920. godine, kada je u listu Pravda zabilježen oglas "da je to prvi muslimanski fotoatelje u Sarajevu. Vlasnik fotoateljea je Muradif Karahasanović”. ${ }^{56}$ Drugi i mnogo značajniji podatak jeste učešće Karahasanovića na izložbi fotografija 13. zagrebačkog zbora održanog od 14. do 15. aprila 1930. godine. ${ }^{57}$ Izložba je bila revijalna

${ }^{53}$ Momir Milojević, “Bosna i Hercegovina za vreme Prvog svetskog rata”, u: CRIMEN (IX) 1/2018, Beograd: Pravni fakultet u Beogradu, 2018, 19-37.

${ }^{54}$ Današnja ulica Ćumurija nosila je naziv Zrinjskog od 1919. godine do poslije agresije na Bosnu i Hercegovinu 1992-1995. Opširnije vidjeti: Alija Bejtić, Ulice i trgovi Sarajeva, Sarajevo: Muzej grada Sarajeva, 1973, 393-394.

${ }^{55}$ A. Bejtić, Ulice i trgovi Sarajeva, 245-246.

Graditeljska cjelina - Hotel Stari Grad (nekadašnji han Gazi Husrev-begovog vakufa, Hotel Gazi) u Sarajevu. Vidi: http://old.kons.gov.ba/main.php?id_struct=6\&lang=1\&action=view\&id=3005 (pristupljeno: 21. 8. 2020)

${ }^{56}$ Pravda, Sarajevo: Daniel \& A. Kajon, 1920, br. 129, 4.

${ }^{57}$ Lovorka Magaš, "Izložba DeutscherWerkbunda Film und Foto na zagrebačkoj Međunarodnoj fotografskoj izložbi i hrvatska fotografija početkom 1930-ih”, u: Radovi Instituta za povijest umjetnosti, br. 34, Zagreb: Institut za povijest umjetnosti, 2010, 189-200. 
i žirirana, a radovi amaterskih i profesionalnih fotografa iz cijele Kraljevine Jugoslavije predstavljeni u zasebnim odjeljenjima. ${ }^{58}$ Tokom 1932. i 1933. godine u Islamskom svijetu reklamira se Foto: Enisa M. Karahasanović, Sarajevo, koji nudi izradu fotografija na svili i svilenim maramicama, dok se isti oglas objavljuje i naredne godine uz izmjene u nazivu, Foto M. Karahasanović, Sarajevo. ${ }^{59}$ U listu El-Hidaje 1937. godine u okviru članka Proslava Mevlidi-šerifa publikovana je fotografija pod naslovom Prizor sa đačke proslave Mevlidi-šerifa u haremu Careve džamije s potpisom Foto: Karahasanović. ${ }^{60} \mathrm{U}$ zaostavštini Marice Vojnović nalaze se dvije fotografije s pečatom sarajevskog fotografskog ateljea Muradifa Karahasanovića: Portret mlade žene u tradicionalnoj muslimanskoj nošnji i Portret dječaka s drvenim konjićem ${ }^{61} \mathrm{U}$ pitanju su studijski portreti na kojima se uočava novi pristup u osvjetljenju figure i lica, te potenciranju individualnosti portretisane osobe kroz vlastite elemente (nakit, odjeća, igračka), što zasigurno predstavlja iskorak ka umjetničkoj portretnoj fotografiji.

Svršenik Akademije za fotografiju u Beču dvadesetih godina 20. stoljeća Ivica Lisac (1895-1973) otvorio je fotoatelje u Titovoj ulici u Sarajevu 1920. godine. ${ }^{62}$ Bio je portretist građanstva, te majstor studijske fotografije, što se vidi na fotografijama iz zaostavštine. Predrag Finci ističe da su "njegove fotografije [su] bile znak jednog doba, ljude koje je snimio slika dostojanstvene, zauvijek iščezle građanske srednje klase, za koje su stariji govorili da su starosjedioci, poslije, u moje vrijeme da su gospoda, a djeca im gradske face i

\footnotetext{
${ }^{58}$ Isto, 193.

${ }^{59}$ Islamski svijet, Sarajevo: [s . n.], 1932, br. 5, 8; 1932, br. 7, 8; 1932, br. 9, 8; 1932, br. 10, 8; 1932, br. 12,$8 ; 1932$, br, 16,$8 ; 1932$, br. 18,$6 ; 1933$, br. 21,$8 ; 1933$, br. 22 , 20; 1933 , br. 24,$8 ; 1933$, br. 25,8 ; $1933,26,8 ; 1933$, br. 37,$8 ; 1934$, br. $75,7$.

${ }^{60}$ El-Hidaje, Sarajevo: ELHIDAJE / Organizacije ilmijje Kraljevine Jugoslavije u Sarajevu, 1937, god. I, br. 7-8, 107.

${ }^{61}$ KV FZMV, inv. br. 1996/16. Fotografski Atelier M. Karahasanović. Sarajevo. Portret mlade žene u tradicionalnoj muslimanskoj nošnji. Ne prije 1920. - ne poslije 1930 i KV FZMV, inv. br. 1996/29. Foto Atelier M. Karahasanović. Sarajevo. Portret dječaka s drvenim konjićem. Ne prije 1930. ne poslije 1940. Vidi: slajd 35-36, https://www.zavicajnimuzej.com/wp-content/uploads/2020/05/ MaricaVojnovicbosanski.pdf.

${ }^{62}$ Vidi: Pokop.ba Sarajevo. http://www.pokop.ba/pretraga-umrlih (pristupljeno: 25. 7. 2020)
} 
gradska raja" ${ }^{63}$ Jedan je od rijetkih fotografa kojem je pošlo za rukom spajanje fotografije s bojom i kistom, ${ }^{64} \mathrm{u}$ čemu se ogleda njegovo poznavanje umjetnosti i slikarstva. Na jednoj od fotografija Ivice Lisca, koja se nalazi u zaostavštini Marice Vojnović, u donjem desnom uglu nalazi se logo ateljea na kojem je ispisano velikim slovima: Odlikovan na Svjetskoj izložbi u Rimu i Sarajevu.

Godine 1935. u Islamskom glasu objavljena je bajramska čestitka Foto Rekorda, koji se nalazio u Ulici Zrinjskog 11 (Sarajevo). Bajram također čestita Atelier Foto - Korso, Ulica Kralja Petra br. 8 (Sarajevo) ${ }^{65}$ Foto Rekord snima portret dječaka na terenu, u ambijentu bašte. ${ }^{66}$ Atelier Foto Korso snima studijsku fotografiju mladog bračnog para ističući portrete na zagasitoj, smeđoj pozadini bez detalja ${ }^{67}$

Foto Narančić, Aleksandrova 53 u Sarajevu, oglasio se u Telefonskom imeniku iz 1941. godine gdje je predstavio svoj fotoatelje. ${ }^{68} \mathrm{Na}$ istoj adresi bio je i Foto Hedda. Obojicu portretista krase oštrina, jasnoća, prozračnost i osvjetljenje kompozicije. Foto Narančić uspijeva "uhvatiti" cijelu figuru dječaka i umiren izraz njegovog lica ${ }^{69} \mathrm{Na}$ fotografijama bliskih prijateljica Marice Vojnović Foto Hedda naglašava istančan smisao za studijski portret, kojem polazi za rukom ideja da portretisano građanstvo dobije novu dimenziju stvarnosti nalik onoj bezvremenskoj holivudskoj. ${ }^{70}$

${ }^{63}$ Predrag Finci, "Fotografija. Oko jučerašnjeg svijeta", dostupno: nomad.ba, 21. 6. 2019. https:// nomad.ba/finci_spomenik_vlastitom_zivotu (pristupljeno: 15. 7. 2020)

${ }^{64}$ KV FZMV, inv. br. 1996/48; 1996/49; 1996/96. Ivica Lisac. Sarajevo. 1920. - ne poslije 1973. Vidi: slajd 25-26, https://www.zavicajnimuzej.com/wp-content/uploads/2020/05/MaricaVojnovicbosanski. pdf.

${ }^{65}$ Islamski glas, Sarajevo: Muhamed Pandža, 1935, br. 13, 13.

${ }^{66}$ KV FZMV, inv. br. 1996/51. Foto Rekord. Sarajevo. Studijski portret mladića i djevojke. Ne prije 1930. - ne poslije 1939.

${ }^{67}$ KV FZMV, inv. br. 1996/ 32. Atelier Foto - Korso. Sarajevo. Portret malog dječaka. Ne prije 1930. - ne poslije 1939.

${ }^{68}$ Miljenko Jergović, “Oglasi u telefonskom imeniku za 1941, treći dio”, Radiosarajevo.ba, 7. 7. 2014. Vidi: Radio Sarajevo, https://radiosarajevo.ba/kolumne/miljenko-jergovic/mehanicarska-radnjaza-popravku-cipela/157757 (pristupljeno: 1. 7. 2020)

${ }^{69}$ KV FZMV, inv. br. 1996/31. Foto Narančić. Sarajevo. Studijska fotografija dječaka Radmila, 1941. Vidi: slajd 27, https://www.zavicajnimuzej.com/wp-content/uploads/2020/05/MaricaVojnovicbosanski.pdf. ${ }^{70}$ KV FZMV, inv. br. 1996/ 73; 1996/53. Foto Hedda. Sarajevo. Ne prije 1929. - ne poslije 1934. Vidi: slajd 
Fočak Nikola Drakulić bio je fotograf, scenograf i filmski snimatelj. Svoje fotografske usluge nudio je oglašavajući se u telefonskim imenicima i to kao "Nikola Drakulić iz Prestolonasljednika Petra 42. Broj telefona: 38-56"71 Fotografija iz zaostavštine Marice Vojnović predstavlja studijski portret tek vjenčanih mladenaca nastao 1938. godine. ${ }^{72}$ Djeluje poput zaustavljene filmske scene ili izrezanog kadra iz filma o ljubavi i sreći. Zasigurno da su grančice ruzmarina kojima su mladenci okićeni ujedno i atributi kojima fotograf naznačava ljubav i bračnu vjernost. Bio je jedan od rijetkih sarajevskih fotografa koji je doprinio razvoju kinematografije u Bosni i Hercegovini snimivši više dokumentarnih i prvi zvučni film. Dejan Kosanović predstavlja Nikolu Drakulića kao jednog od najznačajnijih pionira dokumentarnog i zvučnog bosanskohercegovačkog filma u periodu između dva svjetska rata. Njegov kratki zvučni igrani film pod nazivom Ljubav u Sarajevu (1937) predstavlja začetak bosanskohercegovačkog igranog filma. ${ }^{73}$ Nikola Drakulić je autor i fotomonografije s putovanja na Bali koja je štampana u dva izdanja. ${ }^{74}$

Diplomirani fotograf odlikovan Zlatnom medaljom na Međunarodnoj izložbi fotografije u Firenci $1934 .{ }^{75}$ neumorni fotoreporter i istraživač, hroničar Sarajeva Nusret Halačević (1908 - 14. 10. 1979) imao je fotoatelje na Baščaršiji, preko puta Vijećnice, otvoren dvadesetih godina prošlog stoljeća. Jergović u članku Oglasi u Telefonskom imeniku za 1941 - treći dio donosi oglas iz Halačevićevog studija: "koji se oglasio u telefonskom imeniku, širinom

28-29, https://www.zavicajnimuzej.com/wp-content/uploads/2020/05/MaricaVojnovicbosanski.pdf.

${ }^{71}$ M. Jergović, “Oglasi u telefonskom imeniku za 1941, treći dio", dostupno: https://radiosarajevo. ba/kolumne/miljenko-jergovic/mehanicarska-radnja-za-popravku-cipela/157757 (pristupljeno: 1. 7. 2020)

${ }^{72}$ KV FZMV, inv. br. 1996/47. Foto - Nikola Drakulić. Sarajevo. Studijski portret Martina i Fine Mihaliček, 1938.

${ }^{73}$ Dejan Kosanović, “Ljubav u Sarajevu”, u: Sineast, 1. 9. 1998. br. 107, god. 29, Sarajevo: Kino savez Bosne i Hercegovine, 76-80.

${ }^{74}$ Nikola Drakulić, The Hague, Netherlands - Bandung, Indonesia, The Hague: W. van Hoeve LTD, 1951, Prvo izdanje. Vidi: https://openlibrary.org/books/OL6111859M/Bali. (pristupljeno: 25. 7. 2020)

75 "Na velesajmu u Firenci u Italiji, koji je održan prošlog mjeseca, izlagao je i svoje najuspjelije radove i poznati sarajevski fotograf Nusret ef. Halačević. Lijepi radovi g. Halačevića naišli su na zasluženo priznanje, pa je odlikovan zlatnom medaljom i svečanom diplomom, koje su mu zadnjih dana uručene." Vidi: Islamski svijet, Sarajevo: [s. n.], 1934, br. 95, 5. 
margine nogu, na pedesetsedmoj stranici. Njegov je oglas (ćirilicom) možda tekstualno i najnabijeniji: FOTO N. Halačević, Sarajevo, Kočićeva ul. 14 Telefon 37-84 - Atelje za modernu fotografiju, izrada svih povećanja, bez obzira na stanje slike. Slike na porcelanu za nadgrobne spomenike. Najveći izbor razglednica Sarajeva na veliko i malo. Knjižare i trafike uz veliki popust. Pomoćna radnja Petra Preradovića 7. Specijalni odio za amatere. Brza i stručna izrada uz mnogo umjerene cijene." ${ }^{\text {76 }}$ Fotografija Nusreta Halačevića iz zaostavštine Marice Vojnović spada u dopisnu kartu s fotografijom datiranu pečatom autora na 8 . novembar 1935 . godine. ${ }^{77}$ Snimak predstavlja studijski portret na kojem je prikazana cijela figura mlade djevojke odjevene u bogatu, tradicionalnu, muslimansku nošnju. Malo je poznato da je bio i veliki vakif koji je svoju nepokretnu imovinu predao u vlasništvo Islamskog teološkog fakulteta u Sarajevu 1978. godine. Danas se na njegovom vakufu u Sarajevu gradi centar za Kuran i sunnet. ${ }^{78}$ Priču o Halačeviću donosi Radio Sarajevo u kojoj se, između ostalog, navodi da su njegove fotografije na poleđini nosile modri pečat 'foto N. Halačević ili 'Autorsko pravo Foto N. Halačević Sarajevo.79

Godine 1943. u Narodnoj Uzdanici" reklamirao se sarajevski Foto "Šeher" čija je portretna fotografija sastavni dio zaostavštine. ${ }^{81}$

Snažan utjecaj na razvoj fotografije u Visokom ostavio je Muhamed Konjičanin (1907-1974), profesionalni fotograf, novinar, pisac i pjesnik. ${ }^{82}$

${ }^{76}$ M. Jergović, "Mehaničarska radnja za popravku cipela/Oglasi u telefonskom imeniku za 1941, treći dio", dostupno: https://radiosarajevo.ba/kolumne/miljenko-jergovic/mehanicarska-radnjaza-popravku-cipela/157757 (pristupljeno: 1. 7. 2020)

${ }^{77}$ KV FZMV, inv. br. 1996/147. Foto Atelje Nusret Halačević. Sarajevo. Studijski portret djevojke u tradicionalnoj muslimanskoj nošnji, 8. novembar 1935.

${ }^{78}$ Mustafa Hasani et al, Vakifi, stipenditori i donatori Fakulteta islamskih nauka, Sarajevo: FIN, 2017, 162-164.

79 “FOTO: Lica sarajevskih ulica između dva svjetska rata (I dio)", Radio Sarajevo.ba, 3. 11. 2014. Vidi: https://radiosarajevo.ba/metromahala/teme/foto-lica-sarajevskih-ulica-izmedu-dva-svjetskarata-i-dio/170123 (pristupljeno: 25. 7. 2020)

${ }^{80}$ Narodna uzdanica, 1943, god. XI.

${ }^{81}$ KV FZMV, inv. br. 1996/71. Foto “Šeher”. Sarajevo. Studijski portret žene. Ne prije 1940. - ne poslije 1950.

${ }^{82}$ KV FZMV, inv. br. 1996/133-134; 1996/136-137. Foto Konjičanin. Visoko. Marica Vojnović s prijateljicama. Ne prije 1940. - ne poslije 1955. Vidi: slajd 37-38, https://www.zavicajnimuzej. com/wp-content/uploads/2020/05/MaricaVojnovicbosanski.pdf. 
Bio je član visočkog fotokluba (1948) i jedan od glavnih hroničara Visokog. ${ }^{83}$ Prvi je fotograf koji je snimio užase katastrofe kakanjskih rudara 1934. godine. ${ }^{84}$ Pažnju je posvetio umjetničkoj i dokumentarnoj fotografiji. Umjetničke fotografije snimljenih portreta odišu tajanstvenim osvjetljenjem, dubokim valerskim ključem, naglašenim crno-bijelim kontrastom, a likovi snažnom individualnošću. Jedna od takvih je i Portret prvog muftije $u$ Visokom Husnije ef. Numanagića koja se nalazi u visočkom Zavičajnom muzeju ${ }^{85}$ Fotografije dokumentarnog karaktera, nastale u poslijeratnom periodu, imaju historijski značaj i objavljivane su u listu Naš život. ${ }^{86}$

Muhamed Konjičanin završio je osnovnu školu na Kraljevcu, dok je fotografski zanat izučio kod svog oca fotografa Alifakira Konjičanina koji je u drugoj deceniji 20. stoljeća imao fotografsku radnju za koju se pretpostavlja da je prva u Visokom. U tom periodu očev atelje postaje mjesto okupljanja amaterskih fotografa poput ing. Milenka Gavrilovića, Ferde Kajzera i ing. Dude Montilja s kojima upoznaje socrealizam koji slijedi u svom radu do Drugog svjetskog rata. ${ }^{87}$ Nakon očeve smrti 1930. godine fotografsku radnju u ulici Hamam preuzima majka Džula, udova Alifakira u kojoj Muhamed fotografiše i radi. ${ }^{88}$ Prvo osamostaljivanje nastupa

${ }^{83}$ Prema Idrizu Džajiću, M. Konjičanin autor je većine fotografija koje ilustriraju rad nacionalnih kulturno-prosvjetnih društava u Visokom. Vidi: I. Džajić, Djelovanje nacionalnih kulturnoprosvjetnih društava u Visokom 1903-1949, 207.

84 "In memoriam: Muhamed Konjičanin", Naš život, Visoko: Centar za informisanje i dokumentaciju, februar 1974, br. 93, god. XXII, 13.

${ }^{85}$ F ZMV, Period pred II svjetski rat, inv. br. 915/210. Ne prije 1930. - ne poslije 1931. Objavljeno: Džajić, Djelovanje nacionalnih kulturno-prosvjetnih društava u Visokom 1903-1949, 203.

${ }^{86}$ Jedna od prvih poslijeratnih fotografija M. Konjičanina koja je objavljena u novinama jeste ona sa održanog velikog mitinga građana u Visokom, 1. maja 1945. godine, povodom oslobođenja od fašizma. Vidi: Foto Konjičanin, "Dani oslobođenja”, Naš život, Visoko: Socijalistički savez radnog naroda - Visoko, 7. april 1953, broj 4, god. I, 1.

${ }^{87}$ Nataša Šahinović, "Iz djelatnosti fotoamaterizma u Visokom”, tekst s otvaranja izložbe 1. 4. 1977. Izložba je realizovana u organizaciji Fotokluba i Zavičajnog muzeja Visoko. Otvorena je u prostorijama Likovnog ateljea Visoko 1. - 8. 4. 1977. Arhiva Zavičajnog muzeja Visoko - dokumentacija povremenih tematskih izložbi.

${ }^{88}$ Registar zanatskih radnji sreza visočkog od 1909-1955, Visoko: Opštinski arhiv opštine Visoko, JU Zavičajni muzej Visoko, 36. 
već 1934. kada otvara sahačijsku radnju u Ulici kralja Aleksandra u blizini zgrade današnjeg Zavičajnog muzeja. U tom periodu Konjičanin se aktivno bavi i fotografijom pa je 1943. godine otvorio fotografsku radnju Foto Konjičanin Visoko u istoj ulici. Fotografsku radnju 1951. godine preselio je u novi poslovni prostor u blizini današnje zgrade Gradske uprave Visoko. ${ }^{89}$ Nakon Drugog svjetskog rata bio je odbornik za prosvjetu u Narodnom odboru Visoko i član Školskog odbora. Značajan je njegov doprinos u formiranju Zavičajnog muzeja u Visokom, Kulturno-umjetničkog društva "Ognjen Prica" Visoko, Narodnog univerziteta i prve redakcije visočkog lista Našživot..$^{90}$

Atelje Đuro ili Đorđe Božić iz Sarajeva djelovao je u periodu od 1920. do pred Drugi svjetski rat. Njegove fotografije poznatih ličnosti, portreti, urbani i tradicionalni motivi na gradskim scenama govore o njegovoj studijskoj i fotoreportažnoj djelatnosti. ${ }^{91}$ Bez dovoljno informacija o radu, a ne umanjujući njihov doprinos razvoju fotografije, vrijedi spomenuti i Foto Atelier V. Markotić iz Zavidovića i Foto Gubić iz Sarajeva. ${ }^{92}$

\footnotetext{
${ }^{89}$ Isto, 44,61,88.PodatakolokacijiustupionamjeVisočaninZdenko Antović(1957.). Fotografskaradnja M. Konjičanina nalazila se u porodičnoj kući apotekara Filipa Bohačeka u kojoj se Antović rodio. Vidi i: https://visoko.co.ba/tragom-starih-fotografija-sajdzijska-radnja-muhameda-konjicanina (pristupljeno: 14. 7. 2020)

${ }^{90}$ I. Džajić, Djelovanje nacionalnih kulturno-prosvjetnih društava u Visokom 1903-1949, 206-209.

${ }^{91}$ KV FZMV, inv. br. 1996/74. Atelje Đ. Božić. Sarajevo. Studijski portret dame sa šeširićem. Ne prije 1920. - ne poslije 1930. Vidi: slajd 34, https://www.zavicajnimuzej.com/wp-content/uploads/ 2020/05/MaricaVojnovicbosanski.pdf. Božić je tokom djelovanja kao fotograf koristio više pečata fotoateljea sa svojim imenom. Na fotografiji "Polaznice kursa 4a", inv. br. 8064, Muzej grada Sarajeva, pojavljuje se isti četvrtasti pečat Đ. Božića kao na fotografiji u Zavičajnom muzeju. Vidi: Visual Archive Southeastern Europe. http://gams.unigraz.at/search/gsearch?queryAsAnd=bo\%C5\%BEi\% C4\%87\&hitPageSize $=10$ \&hitPageStart $=1$ \&mode $=$ simpleSearch\&pid $=$ vif\&x2=http\%3A $\% 2 F \% 2 F g a$ ms.uni-graz.at\%2Fvase\%2F3vif-search.xsl (pristupljeno: 13. 7. 2020)

${ }^{92}$ KV FZMV, inv. br. 1996/68. Foto Atelier V. Markotić. Zavidovići. Fotografija dame. Ne prije 1930. - ne poslije 1935. i KV FZMV, inv. br. 1996/52. Foto Gubić. Sarajevo. Studijska fotografija mladića i djevojke, 1955.
} 
Tabelarni pregled djelovanja fotografa i fotoateljea na teritoriji Bosne i Hercegovine zastupljenih u fotografskoj građi iz zaostavštine Marice Vojnović u Zavičajnom muzeju Visoko

\begin{tabular}{|c|c|c|c|}
\hline Naziv fotografa / fotoateljea & $\begin{array}{c}\text { Okvirni period } \\
\text { djelovanja }\end{array}$ & Adresa & Napomena \\
\hline Fotograf Grimberg & $1890-1912$. & Višegrad & \\
\hline Seraphine Sperling & $1890-1912$. & Višegrad & Priboj, Srbija \\
\hline Visit Portrait (?) & 1890-1910. & Višegrad (?) & \\
\hline Cabinet Portrait (?) & 1895-1907. & Višegrad (?) & \\
\hline Samuel S. Abinun & $1895-1915$. & Sarajevo & \\
\hline EM. (Emanuel/Emil) Buchwald & $1895-1918$. & Sarajevo & \\
\hline Veljko Đ. (Đurov) Simović & 1896-1916. & $\begin{array}{l}\text { Bileća } \\
\text { Nevesinje }\end{array}$ & \\
\hline Färber Heinrich & 1900-1920. & Sarajevo & \\
\hline Elektro-Fotograf & $1905-1918$. & Sarajevo & \\
\hline Walter Tausch & $1908-1945$. & Sarajevo & \\
\hline M. Karahasanović & 1918-1939. & Sarajevo & \\
\hline Đ. (Đuro ili Đorđe) Božić & 1920-1940. & Sarajevo & \\
\hline Ivica Lisac & $1920-1973$. & Sarajevo & \\
\hline Nusret Halačević (1908-1979) & 1926-1979. & Sarajevo & \\
\hline Foto Hedda & 1929-1934. & Sarajevo & \\
\hline V. Markotić & 1930-1940. & Zavidovići & \\
\hline Foto Rekord & $1930-1945$. & Sarajevo & \\
\hline Atelier Foto - Korso & $1930-1945$. & Sarajevo & \\
\hline Nikola Drakulić & $1930-1984$. & Sarajevo & Bali, Indonezija \\
\hline Muhamed Konjičanin (1907-1974) & $1930-1974$. & Visoko & \\
\hline Foto Narančić & $1935-1945$. & Sarajevo & \\
\hline Foto Šeher & $1940-1955$. & Sarajevo & \\
\hline Foto Gubić & $1950-1960$. & Sarajevo & \\
\hline
\end{tabular}




\section{Zaključak}

Cjelokupna zaostavština Marice Vojnović dio je fundusa Zavičajnog muzeja u Visokom od 1981. godine. Najobimniju građu zaostavštine čini fotografski materijal koji okvirno pripada periodu kraja 19. do sedamdesetih godina 20. stoljeća. Na većini fotografija dominantan je portret, što upućuje na zaključak da je primarna žanrovska orijentacija fotografa bio studijski portret. Međutim, tu su i snimanja na otvorenom, dokumentiranja različitih dešavanja, poput vojničkih zabava, proslava i vjenčanja.

$\mathrm{Na}$ osnovu analize fotografske građe iz zaostavštine zabilježen je rad 23 fotografa koji su imali fotoateljee u Sarajevu, Višegradu, Visokom, Nevesinju i Zavidovićima. Grimberg, Seraphine Sperling, Visit Portrait, Cabinet Portrait, Samuel Abinun, Emanuel Buchwald i Färber Heinrich imena su prvih fotografskih ateljea, koji se otvaraju na tlu Bosne i Hercegovine nakon 1878. godine. Značajna je njihova uloga u historiji bosanskohercegovačke fotografije. Oni se specijaliziraju za izradu kabinetskih fotografija i fotografija tipa vizitkarte. Fotografija malog ili minijaturnog formata primjenjivog za lična dokumenta razvija sarajevski studijski portretista Elektro-Fotograf, koji snima portrete pod blještavom vještačkom svjetlošću. Za razliku od njega, nevesinjski fotograf Veljko Đ. Simović grupne portrete porodičnih slava smješta u prirodni ambijent seoskog gazdinstva i među prvim domaćim fotografima snima "eksternu" fotografiju pod otvorenim nebom i prirodnom svjetlošću. S druge strane, nailazimo na fotografe koji su začetnici novih pravaca u fotografiji: dokumentarna, reportažna, umjetnička i filmska fotografija. Pionir dokumentarne fotografije u Bosni i Hercegovini bio je Walter Tausch. Polet razvoju umjetničke fotografije dali su akademski fotografi Ivica Lisac, Nusret Halačević i Muradif Karahasanović koji su izlagali na svjetskim izložbama u Rimu, Firenci i Zagrebu tridesetih godina prošlog stoljeća. Na portetima Muhameda Konjičanina primjetan je utjecaj elemenata socrealističkog žanra, dok Foto Hedda i Nikola Drakulić fotografiju pretvaraju u kadar ili filmsku umjetnost. 
Ova vrijedna građa predstavlja neodvojivi dio bosanskohercegovačke fotografske baštine i njen je značaj višestruk. Izvor je informacija za različita etnološka i historijska istraživanja na teritoriju Bosne i Hercegovine, ali i šire, prikazujući kontinuitet razvoja fotografije, te pojavu fotografskih ateljea u Bosni i Hercegovini.

\title{
IZVORI I LITERATURA
}

\author{
Izvori
}

\section{Zavičajni muzej Visoko (ZMV)}

Fototeka Zavičajnog muzeja Visoko (F ZMV), Kolekcija fotografija iz zaostavštine Marice Vojnović (KV FZMV).

Arhiva Zavičajnog muzeja - dokumentacija povremenih tematskih izložbi, 1977.

Opštinski arhiv opštine Visoko, Registar zanatskih radnji sreza visočkog od 1909-1955.

\section{Štampa}

Bosanski glasnik: opći adresni priručnik sa kalendarom svih vjeroispovjesti za Bosnu i Hercegovinu = Bosnicher Bote, Universal - Hand und Adressbuch nebst Kalender für alle Conffesiones für Bosnien - Hercegovina, Izdavač i urednik: Adolf Walny. Sarajevo / Beč, 1897-1918.

Bosanska vila, Sarajevo: Srpsko prosvjetno-kulturno društvo Prosvjeta, 1896.

Bosanski vjestnik, Sarajevo: Sopronova pečatnja, 1866.

Bošnjak: kalendar za prostu godinu 1911. Sarajevo: Zemaljska tiskara, 1911. El-Hidaje, Sarajevo: El Hidaje / Organizacija ilmijje Kraljevine Jugoslavije, 1937.

Islamski glas, Sarajevo: Muhamed Pandža, 1934.

Islamski svijet, Sarajevo [s. n.], 1934. 
Narodna Uzdanica, Sarajevo: Državna tiskara - Tiskara Bosanske štampe, 1923-1940.

Naš život: list narodnog fronta sreza visočkog (1953-1987). Visoko: Centar za informisanje i dokumentaciju.

Pravda, Sarajevo: Daniel \& A. Kajon, 1920.

Sarajevski list, Sarajevo: Zemaljska tiskara, 1878-1918.

Sineast, Sarajevo: Kino savez Bosne i Hercegovine, 1998.

\section{Literatura}

\section{Knjige}

Bejtić, Alija, Ulice i trgovi Sarajeva, Sarajevo: Muzej grada Sarajeva, 1973.

Debeljković, Branibor, Stara srpska fotografija, Beograd: Muzej grada Beograda, Muzej primenjenih umetnosti, 1977.

Džajić, Idriz, Djelovanje nacionalnih kulturno-prosvjetnih društava u Bosni i Hercegovini, Visoko: Agencija za komunikacije i promotivne usluge, BAN, 2014.

Hasani, Mustafa, Jelovac Firdevsa, Kulenović Azra, Vakufi, stipenditori i donatori Fakulteta islamskih nauka, Sarajevo: FIN, 2017.

Freund, Gisele, Fotografija i društvo, Zagreb: Grafički zavod Hrvatske, 1981.

Marušić, Nikola, Istorija fotografije u Bosni i Hercegovini do 1918, Tuzla: Foto-savez Bosne i Hercegovine, 2002.

Todić, Milanka, Istorija srpske fotografija (1839-1940), Beograd: Prosveta; Muzej primenjenih umjetnosti, 1993.

Younis, Hana, Svakodnevni život u Sarajevu 1850-1878, Sarajevo: Centar za osmanističke studije, 2019.

Younis, Hana, Od dućana do pozorišta: Sarajevska trgovačka elita 1851-1878, Sarajevo: Institut za historiju, 2017. 


\section{Članci}

Gozze-Delić, Vesna, "Fotografija kao muzejski predmet ili kao muzejska dokumentacija”, u: Informatica museologica, Vol. 31, No. 3-4, Zagreb: Muzejski dokumentacioni centar, 2000, 17-18.

Leka, Alma, "Udruženje profesionalnih fotografa Bosne i Hercegovine i Društvo amater fotografa Sarajevo" (Iz rada prvih bosanskohercegovačkih fotografskih društava), u: Historijska traganja, br. 8, Sarajevo: Institut za historiju, 2011, 81-92.

Magaš, Lovorka, "Izložba Deutscher Werkbunda Film und Foto na zagrebačkoj Međunarodnoj fotografskoj izložbi i hrvatska fotografija početkom 1930-ih", u: Radovi Instituta za povijest umjetnosti, br. 34, Zagreb: Institut za povijest umjetnosti, 2010, 189-200.

Maroević, Ivo, “Fotografija kao muzejski predmet”, u: Informatica museologica, Vol. 31, No. 3-4, Zagreb: Muzejski dokumentacijski centar, 2002, 13-16.

Milojević, Momir, "Bosna i Hercegovina za vreme Prvog svetskog rata”, u: CRIMEN (IX) 1/2018, Beograd: Pravni fakultet u Beogradu, 2018, 1937.

\section{Internetski izvori}

Antović, Zdenko, “Tragom starih fotografija: Sajdžijska radnja Muhameda Konjičanina”, Visoko. co. ba, 20. 9. 2017. https://visoko.co.ba/tragom-starih-fotografija-sajdzijska-radnja-muhameda-konjicanina/ (pristupljeno: 17. 7. 2020)

Aukcijska kuća Barac\&Pervan. http://barper.com/ (pristupljeno: 15. 7. 2020)

Drakulić, Nikola, Bali, The Hague, Netherlands - Bandung, Indonesia: W. van Hoeve, Ltd. 1951, 1. izdanje. https://openlibrary.org/books/OL61 11859M/Bali. (pristupljeno: 25. 7. 2020)

FotoMuzej - Virtuelni muzej srpske i svetske fotografije. http://www. fotomuzej.com/atelje-serafin-sperling.266.html (pristupljeno: 8. 6. 2020) 
"Foto: Lica sarajevskih ulica između dva svjetska rata (I dio)", Radio Sarajevo.ba, 3. 11. 2014. https://radiosarajevo.ba/metromahala/teme/fotolica-sarajevskih-ulica izmedu-dva-svjetska-rata-i-dio/170123 (pristupljeno: 25. 7. 2020)

Finci, Predrag, "Fotografija. Oko jučerašnjeg svijeta", osmi dio knjige Spomenik vlastitom životu. Nomad.ba, 21. 6. 2019. https://nomad.ba/finci_spomenik_vlastitom_zivotu (pristupljeno: 15. 7. 2020)

Jergović, Miljenko, “Oglasi u Telefonskom imeniku za 1941, treći dio”, Radio Sarajevo.ba, 7. 7. 2014. https://radiosarajevo.ba/kolumne/miljenkojergovic/mehanicarska-radnja-za-popravku-cipela/157757 (pristupljeno: 1. 7. 2020)

Komisija za očuvanje nacionalnih spomenika Bosne i Hercegovine. http:// kons.gov.ba/?lang=bs (pristupljeno: 21. 8. 2020)

Museum of Family History. http://www.museumoffamilyhistory.com/pse4.htm (pristupljeno: 24. 7. 2020)

Online izložba: Marica Vojnović, Visočanka (1892-1982) - zaostavština predmeta i fotografija s kraja 19. i početka 20. stoljeća. 16. 5. 2020. https:// www.zavicajnimuzej.com/wpcontent/uploads/2020/05/MaricaVojnovicbosanski.pdf (pristupljeno: 26. 8. 2020)

Općina Centar Sarajevo. http://www.centar.ba/ (pristupljeno: 26. 8. 2020) Pokop. ba Sarajevo. http://www.pokop.ba/pretraga-umrlih (pristupljeno: 25. 7. 2020)

Visual Archive Southeastern Europe. https://gams.uni-graz.at/context:vase (pristupljeno: 13. 7. 2020) 


\title{
OVERVIEW OF PHOTOGRAPHERS AND PHOTOGRAPHIC STUDIOS ON THE TERRITORY OF BOSNIA AND HERZEGOVINA THROUGH PHOTOGRAPHIC MATERIAL OF THE LEGACY OF MARICA VOJNOVIĆ IN VISOKO REGIONAL MUSEUM
}

\begin{abstract}
Summary
The entire legacy of Marica Vojnović has been part of the holdings of the Regional Museum of Visoko since 1981. The most extensive material of the legacy is photographic material, which roughly dates back to the period from the end of the 19th century to the 70s of the 20th century. The portrait is a dominant feature in most of the photographs, which suggests that the primary genre orientation of photographers was a studio portrait. However, there are also outdoor shootings, documenting various events such as military parties, celebrations and, weddings.

Based on the analysis of the photographic material of the legacy, the work of 23 photographers who had photo studios in Sarajevo, Višegrad, Visoko, Nevesinje and Zavidovići was recorded. Grimberg, Seraphine Sperling, Visit Portrait, Cabinet Portrait, Samuel Abinun, Emanuel Buchwald and Färber Heinrich are the names of the first photography studios that started operating in Bosnia and Herzegovina after 1878. Their role in the history of Bosnian photography is significant. They specialized in making cabinet photos and business-card-type photos. Small or miniature photography format applicable to personal documents was being developed by Sarajevo-based studio portraitist Elektro-Fotograf, who took portraits in bright artificial light. Unlike him, Nevesinje photographer Veljko Đ. Simović places group portraits of family feasts in the natural ambiance of a rural farm and is among the first domestic photographers to take "external" photography under the open sky and natural light. On the other hand, we come across photographers who are the pioneers of new genres in photography:
\end{abstract}


documentary, reportage, art, and film photography. The pioneer of documentary photography in Bosnia and Herzegovina was Walter Tausch. Academic photographers Ivica Lisac, Nusret Halačević and M. Karahasanović, who exhibited at world exhibitions in Rome, Florence and Zagreb in the 1930s, gave impetus to the development of art photography. The portraits of Muhamed Konjičanin show the influence of elements of the socialist-realist genre, while Foto Hedda and Nikola Drakulić turn photography into a frame or film art.

This valuable material is an inseparable part of the photographic heritage of Bosnia and Herzegovina and its significance is manifold. The source provides information for various ethnological and historical research in the territory of Bosnia and Herzegovina, and even beyond, showing the continuity of the development of photography, and the emergence of photographic studios in Bosnia and Herzegovina. 